\title{
Cell cycle and centromere FISH studies in premature centromere division
}

\author{
Alfredo Corona-Rivera*1,2,5, Fabio Salamanca-Gomez ${ }^{3}$, Lucina Bobadilla- \\ Morales $^{1,5}$, Jorge R Corona-Rivera ${ }^{1,4,5}$, Cesar Palomino-Cueva ${ }^{5}$, \\ Teresa A Garcia-Cobian ${ }^{5}$ and Enrique Corona-Rivera ${ }^{5}$
}

\begin{abstract}
Address: ${ }^{1}$ Laboratorio de Citogenética Genotoxicidad y Biomonitoreo, Instituto de Genética Humana Dr. Enrique Corona Rivera, Departamento de Fisiología, División de Disciplinas Básicas, Centro Universitario Ciencias de la Salud, Universidad de Guadalajara, Guadalajara, Jalisco, México, ${ }^{2}$ Unidad de Citogenética, OPD Hospital Civil Fray Antonio Alcalde, Guadalajara, Jalisco, México, ${ }^{3}$ Unit of Investigation in Human Genetics, National Medical Center, Instituto Mexicano del Seguro Social, México City, México, ${ }^{4}$ División de Pediatría, OPD Hospital Civil Juan I. Menchaca, Guadalajara, Jalisco, México and ${ }^{5}$ Laboratorio de Genética Humana, Departamento de Fisiología, División de Disciplinas Básicas, Centro Universitario Ciencias de la Salud, Universidad de Guadalajara, Guadalajara, Jalisco, México

Email: Alfredo Corona-Rivera* - alcorona@cucs.udg.mx; Fabio Salamanca-Gomez - fasalam@prodigy.net.mx; Lucina BobadillaMorales - lucinabo@cucs.udg.mx; Jorge R Corona-Rivera - rocorona@cucs.udg.mx; Cesar Palomino-Cueva - acorona@cucs.udg.mx; Teresa A Garcia-Cobian - tgcobian2002@yahoo.com.mx; Enrique Corona-Rivera - acorona@cencar.udg.mx

* Corresponding author
\end{abstract}

Published: 20 September 2005

BMC Medical Genetics 2005, 6:33 doi:10.1 |86/|47|-2350-6-33
Received: 09 March 2005

Accepted: 20 September 2005

This article is available from: http://www.biomedcentral.com/I47I-2350/6/33

(C) 2005 Corona-Rivera et al; licensee BioMed Central Ltd.

This is an Open Access article distributed under the terms of the Creative Commons Attribution License (http://creativecommons.org/licenses/by/2.0), which permits unrestricted use, distribution, and reproduction in any medium, provided the original work is properly cited.

\begin{abstract}
Background: Mitotic configurations consistent in split centromeres and splayed chromatids in all or most of the chromosomes or premature centromere division (PCD) have been described in three categories. (I) Low frequency of PCD observed in colchicines-treated lymphocyte cultures from normal individuals. (2) High frequency of PCD with mosaic variegated aneuploidy. (3) High frequency of $P C D$ as a sole chromosome abnormality observed in individuals with no recognizable clinical pattern. We report four members of a family with the third category of PCD.

Methods: Cell cycle duration assessed by average generation time using differential sister chromatid stain analysis and FISH studies of DNA centromere sequences in PCD individuals, are included and compared with previously reported PCD individuals from 9 families.

Results: We observed PCD in colchicine-treated cultures from the propositus, his father, and two paternal aunts but not in his mother and four other paternal and maternal family members, as well as in untreated cultures from the propositus and his father. We observed cytological evidence of active centromeres by $\mathrm{Cd}$ stain. Significative cell cycle time reduction in anaphases of PCD individuals (average generation time of $21.8 \mathrm{~h} ; \mathrm{SD} 0.4$ ) with respect to individuals without PCD (average generation time of $31.8 \mathrm{~h} ; S D$ 3.9) was observed $(P<0.005$, Student $t$-test for independent samples). Increased cell proliferation kinetics was observed in anaphasic cells of individuals with PCD, by differential sister chromatid stain analysis. FISH studies revealed the presence of alpha satellite DNA from chromosomes I, I3, 2I/18, X, all centromeres, and CENP-B box sequences in metaphasic and anaphasic cells from PCD individuals.
\end{abstract}

Conclusion: This report examines evidences of a functional relationship between PCD and cell cycle impairment. It seems that essential centromere integrity is present in these cases. 


\section{Background}

Mitotic configurations consistent in split centromeres and splayed chromatids in all or most of the chromosomes or "premature centromere division" (PCD), have been described in three categories. They are:

(1) Low frequency of PCD (up to 3\% of the mitosis) observed in colchicines-treated lymphocyte cultures from normal individuals $[1,2]$.

(2) High frequency of PCD (5\% or more) with mosaic aneuploidies involving a variety of chromosomes, called "mosaic variegated aneuploidy", observed in individuals with microcephaly, growth deficiency, severe mental retardation, and risk of malignancy [3-5].

(3) High frequency of PCD (5\% or more) as a sole chromosome abnormality [6-10]. Individuals with this condition have no recognizable clinical pattern or occur in healthy individuals. Association of this PCD trait with abortions and infertility has been reported $[6,7,9,10]$, but other authors suggest this PCD trait to be harmless $[1,8,11]$.

We report a family that corresponds to the third category of PCD, in which four individuals showed PCD as a sole chromosome abnormality. Cell cycle duration, assessed by average generation time, and FISH studies of the centromere, are considered. Findings in the family are compared with those on 30 other previously reported individuals with PCD from 9 families. This report examines the evidences of a relationship between PCD and cell cycle impairment of cells bearing main structural centromere components from PCD individuals.

\section{Methods \\ Family data}

A total of nine individuals were available to be studied, five of them from the paternal lineage, four of them from the maternal lineage and the propositus. Infertility was observed in two paternal aunts. Family data are summarized on Fig. 1. The non-consanguineous parents were both aged 27 years at propositus birth. The propositus was born at 36 weeks by abdominal delivery indicated by maternal pre-eclamptic toxemia and showing neonatal hypoxia. Birth weight was $2100 \mathrm{~g}$ and height was $46 \mathrm{~cm}$. Early signs included: hypotonia, strabismus, seizures, recurrent respiratory infections and occasional breathholding spells. Physical examination at 5 years of age showed microcephaly (OFC -4.1 SD), low weight (-4.1 SD) and borderline length (10th percentile); plagiocephaly and brachycephaly, nystagmus, phimosis, right cryptorchidia, adducted thumbs, syndactyly 2-3 of toes, four limbs spasticity and increased deep tendon reflexes. On Xrays, hyperbrachycephaly (cephalic index 91.7), scoliosis, spina bifida occulta (T1-T5), coxa valga, slim bones and osteopenia were found. Cortical and subcortical atrophy was found on cranial CT scan. Brainstem auditory evoked potentials were normal. Psychometric test demonstrated a development age of 3-6 months. The propositus died at 10 years of age by pneumonia. Propositus relatives were phenotypically healthy.

\section{Cytogenetic studies}

We performed GTG banded karyotypes from peripheral blood lymphocyte cultures stimulated by phytohemaglutinin and treated one hour with colchicine (SIGMA, 0.104 $\mu \mathrm{g} / \mathrm{ml})$, in the propositus and eight family members indicated in Fig. 1. On harvesting, 15 minutes of hypotonic treatment $\left(0.075 \mathrm{M} \mathrm{KCl}\right.$ at $\left.37^{\circ} \mathrm{C}\right)$ was performed. Chromosome aberrations in the karyotypes of these individuals were not observed. PCD frequencies in repeated cultures of available individuals were obtained in at least three repeated cultures. Around 100 mitosis were scored per culture giving a total range of 258 to 1142 cells scored per individual (Table 1). To obtain basal frequencies of PCD, ten healthy young individuals were used as controls. Additional simultaneous cultures without mitostatic treatment were performed in the propositus and his parents. Cd staining was performed in the propositus and his parents according to Denton et al. (1977) [12].

\section{Cell cycle studies}

Cellular proliferation kinetics was used to determine the cell cycle duration, which is the interval between one mitosis and the subsequent [13]. The method called average generation time (AGT) by differential sister-chromatid stain $[14,15]$, was used to determine cell cycle durations. We compared the results between family members with more than $5 \%$ of PCD versus those with less than $3 \%$ of anaphase frequencies. The original AGT method [14,15], consider for cell cycle calculations only metaphases, in this family, calculations were also performed considering, prophases, anaphases and total mitotic cells. The procedure was as follows. We obtained AGT's of each individual from accumulated data of 3 simultaneous $72 \mathrm{~h}$ cultures with $5 \mu \mathrm{g} / \mathrm{ml}$ of 5 '-bromodeoxyuridine (SIGMA), added $24 \mathrm{~h}$ after set-up. In each culture, we scored prophases, metaphases and anaphases which had completed either one, two or three cell cycles identified by differential sister chromatid stain pattern. Then, AGT, were calculated per mitotic stage and per individual as follows. (i) Taking into account the percentage of cells at first (M1), second (M2) and third (M3) cell cycle, the replication index (RI) was obtained from this formula: RI= $(1 \mathrm{X} \% \mathrm{M} 1+2 \mathrm{X} \% \mathrm{M} 2+3 \% \mathrm{M} 3) / 100$. (ii) The RI was used to obtain the AGT following the equation: $A G T=$ time of harvest after exposure to 5 '-BrdU/RI. Finally, AGT's were compared in paternal individuals with PCD versus those individuals with low anaphase frequencies from the 

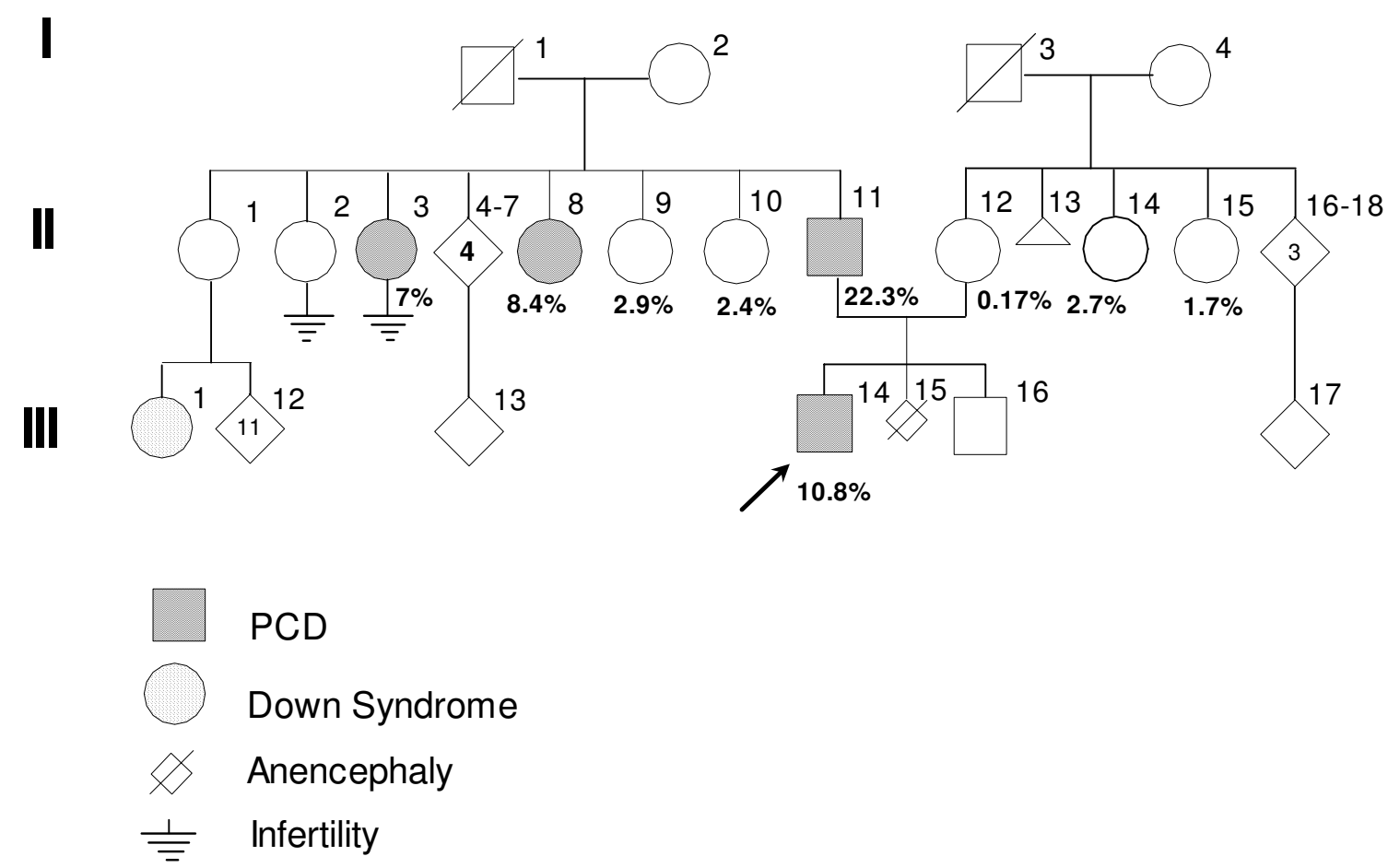

Figure I

Pedigree of the family. Pedigree of the family. PCD frequencies and familial data of investigated individuals are indicated.

maternal sibship. Statistical test t-Student for independent samples was used to compare both groups.

\section{FISH studies}

We searched for the presence of constitutive structural components of the centromere such as alpha satellite DNA sequences in the propositus and his parents with FISH according to a standard protocol [16], using alpha satellite DNA directly labeled probes to chromosomes 1 , $13 / 21,18$, and $\mathrm{X}$, as well as all centromeres probe. Besides, we searched for the presence of CENP-B box sequence in the propositus using a biotin labeled probe, following the protocol of Matera and Ward (1992) [17].

\section{Results}

Cytogenetic studies

PCD frequencies in repeated cultures of available individuals are shown in Table 1. Individuals with PCD of 5\% or more corresponded to the propositus, his father and two paternal aunts (II-3, and II-8). Individuals with less of 3\% of anaphases were considered as normal and corresponded to mother's propositus, two maternal aunts (II14, II-15), and two paternal aunts (II-9, II-10). Basal frequencies of PCD, in ten healthy young individuals used as controls, did not differ with respect to PCD individual with less of 3\% of anaphases. A PCD image of the propositus is shown in figure $2 \mathrm{a}$. In additional simultaneous cultures without mitostatic treatment PCD was observed in the propositus (5\%) and his father (5.5\%), but not in his mother. Two centromeric dots in evident primary constrictions were observed by $\mathrm{Cd}$ staining in the propositus and his parents (fig. 2b). This finding is considered a cytological evidence of active centromeres [12].

\section{Cell cycle studies}

We observed cell cycle duration significatively reduced in anaphasic cells but not in prophasic, metaphasic or total cells (Table 2). Cell cycle reduction was then attributed 
Table I: Percentages of PCD in repetitive colchicine-treated cultures from family members.

\begin{tabular}{lccc}
\hline Family member & No. of cultures & Total mitoses scored & Percent PCD \\
\hline Propositus (III-I4) & 3 & 399 & 10.8 \\
Father (II-II) & 3 & 492 & 22.35 \\
Mother (II-I2) & 3 & 1142 & 0.175 \\
Paternal aunt (II-3) & 2 & 258 & 7.0 \\
Paternal aunt (II-8) & 8 & 586 & 8.36 \\
Paternal aunt (II-9) & 9 & 738 & 2.9 \\
Paternal aunt (II-10) & 7 & 485 & 2.47 \\
Maternal aunt (II-I4) & 7 & 722 & 2.7 \\
Maternal aunt (II-I5) & 7 & 634 & 1.73 \\
Controls & 10 & 980 & 0.87 \\
\hline
\end{tabular}

only to cells in anaphase (PCD cells). Additionally, we observed that in the same culture conditions, $38 \%$ of anaphases in the propositus and his father reached the third cell cycle, while only $15 \%$ of metaphases did. This was interpreted as increased cell proliferation kinetics of anaphasic cells in individuals with PCD associated to cell cycle shortening in PCD cells. Anaphases from second and third cell cycle are shown in figures $2 \mathrm{c}$ and $2 \mathrm{~d}$ respectively.

\section{FISH studies}

We observed in all cases positive fluorescent signals (figure 3a), indicating the presence of all tested sequences. We observed a positive fluorescent signal pattern, indicating the presence of CENP-B box sequence in the propositus (figure 3b).

\section{Discussion}

We report four family members with more than $5 \%$ of colchicine-anaphase frequencies as a sole chromosome abnormality. Nine families have been reported referring to this trait as PCD [6-10]. Mitosis obtained from colchicine arrested lymphocyte cultures of normal individuals, show rates below 3\% [1], 5\% [2] or 1\% observed in our control individuals. Previous reports of PCD frequencies without mosaic variegated aneuploidy (MVA), ranges 5 to $38 \%$ [6-10]. In our family, PCD was observed in the propositus, his father, and two paternal aunts in repeated colchicine-treated cultures in average frequencies of 7 to $22 \%$. It was shown [18], that PCD can be induced through hypotonic increasing time treatment of mitotic cells in peripheral blood lymphocytes of healthy individuals and patients homozygous to PCD trait or PCD and MVA. They found that $0.075 \mathrm{M} \mathrm{KCl}$ at $37^{\circ} \mathrm{C}$ for $20 \mathrm{~min}$, showed 0$2 \%$ cells in PCD which fits with our observed frequencies because 15 minutes of hypotonic treatment were used in our peripheral blood cultures. Total mitosis scored in repeated cultures of previous [6-10], and present report did not provide evidences of MVA. Although PCD is considered a rare phenomenon, two studies found in selected population frequencies of 1 of 100 [1] or 1 of 1000 [11].
Only two previous studies tested cell cycle duration in individuals with PCD as a sole chromosome abnormality (Table 3). In both cases they obtained evidences that the cell cycle time can be altered in PCD individuals [6,7]. Rudd et al. (1983) [6], found reduced metaphase duration only in some cultured cells, supposing that such cells could have corresponded to those with PCD. Gabarrón et al. (1986) [7], inferred that only the cells in anaphase or PCD cells, showed accelerated proliferation kinetics and consequently reduced cell cycle duration. We provide evidences to confirm that cell cycle duration is reduced in PCD cells because only in anaphasic cells the cell cycle duration in the family members with PCD was statistically reduced. Additionally, we observed increased cell proliferation kinetics of anaphasic cells in individuals with PCD. These findings are compatible with the co-existence of cellular subpopulations bearing differential proliferation kinetics. Cell cycle reduction, possibly related to premature separation of centromeres and persistence of anaphases, could then be considered a distinctive finding in these cases.

Cell cycle progression requires control mechanisms that could be associated to PCD origin. A basic defect of cell cycle progression or metaphase-anaphase transition in PCD was suggested [19]. Matsuura et al. (2000) [20], demonstrated that cultured fibroblasts from two infants with PCD and mosaic variegated aneuploidy are insensitive to the colcemid-induced mitotic-spindle checkpoint. Mitchel et al. (2001) [21], found that mitotic checkpoint defective MAD2+/- haploinsufficient human colon carcinoma cells showed $20 \%$ of precocious anaphases with prematurely separated sister chromatids, compared with $1 \%$ in wild-type cells, proposing that PCD is a suitable cytogenetic marker for the identification of mitotic checkpoint defects. In our family PCD was also observed in cultures without colchicine from the propositus and his father as in other PCD reports [6-8] (Table 3). Cultured PCD cells with defective colcemid-induced mitotic-spindle checkpoint reported by Matsuura et al. (2000) [20], 


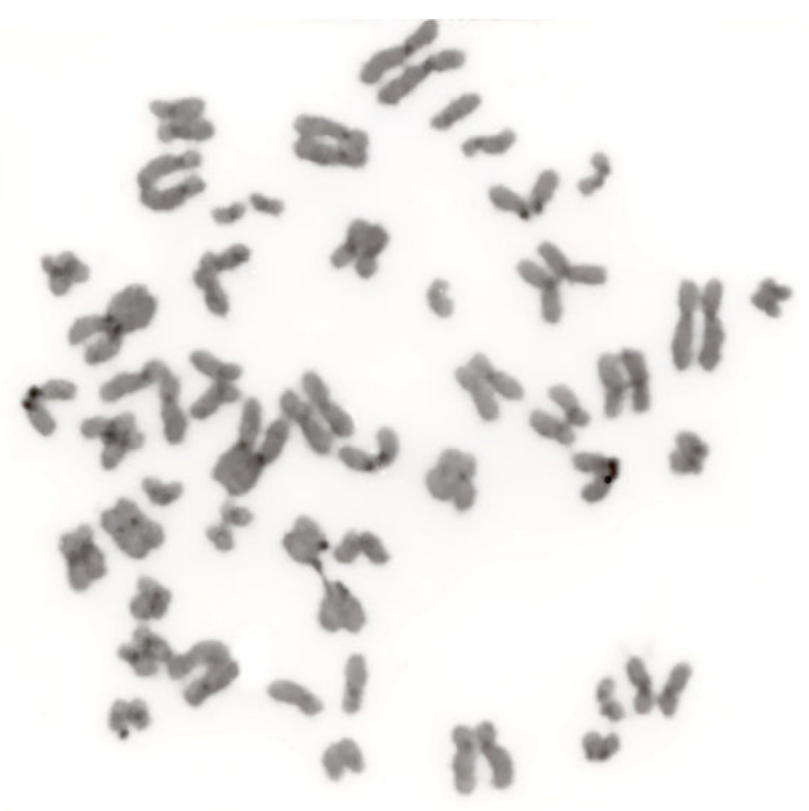

a
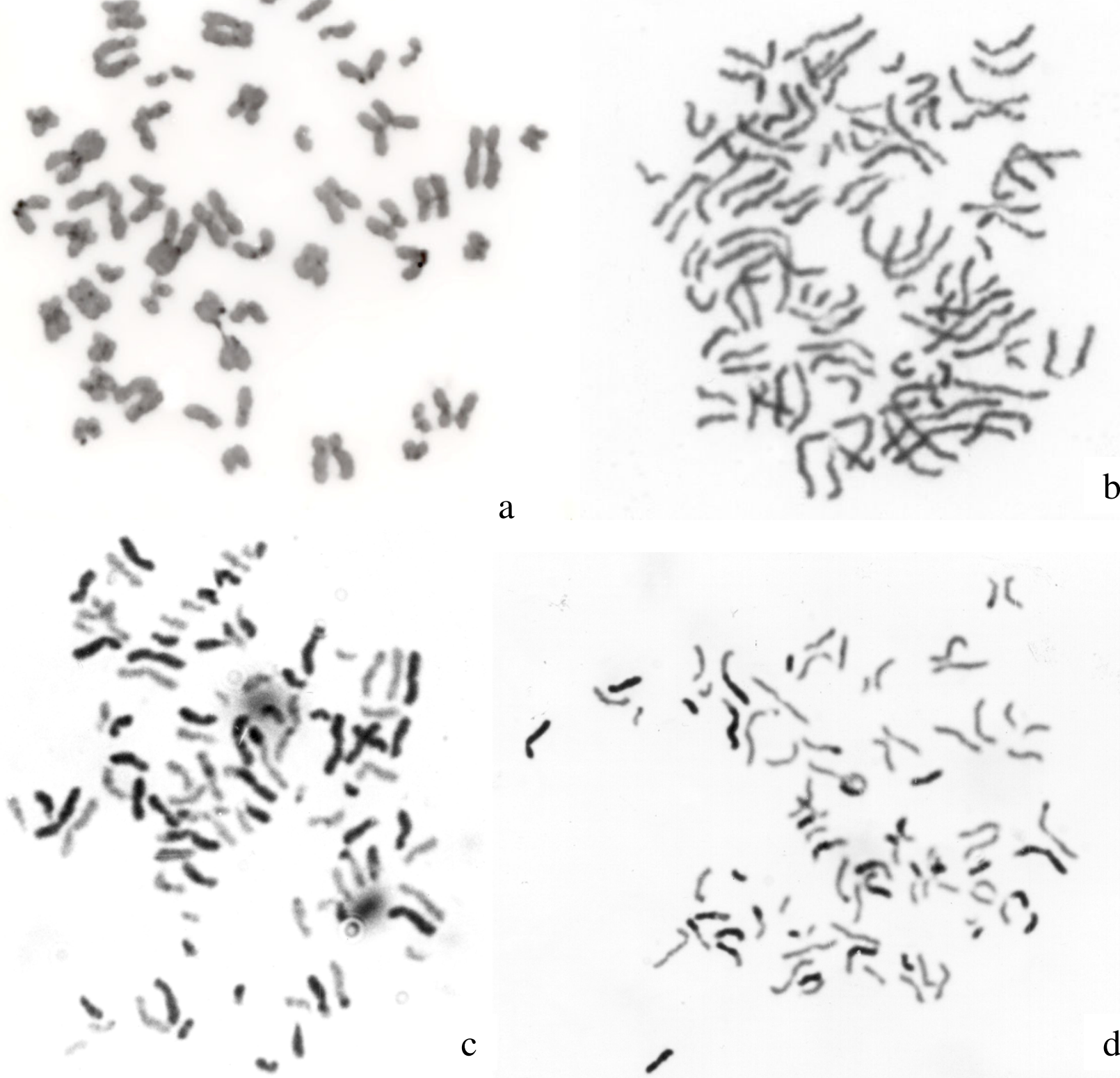

Figure 2

PCD figures. Propositus PCD figures are shown with Cd stain (a), giemsa stain (b), and sister chromatid differential stain from second (c), and third (d), cell cycle.

were unresponsive to colchicine. Although in our family MVA was not observed as in Matsuura et al. (2000) [20] report, in both cases the mitotic arrest signal was overruled in PCD cells. Hanks et al. (2004) [22], provided the evidence that gene mutations can result in a defective spindle checkpoint in humans. They screened the full coding sequence and intron-exon boundaries of $B U B 1 B$, and found truncating and missense mutations inherited from different parents in five of eight families with mosaic variegated aneuploidy providing the first evidence in humans that gene mutations might be responsible for aneuploidy in human cancers. Interestingly, cytogenetic 
Table 2: Cell cycle durations in paternal sibship with PCD (paternal aunt II-8, propositus III-I 4, father II-I I) versus maternal sibship without PCD (maternal aunts II- 14 and II-I5, mother II-I2).

\begin{tabular}{|c|c|c|c|c|}
\hline \multirow[t]{2}{*}{ Groups } & \multicolumn{4}{|c|}{ Average generation time } \\
\hline & Prophases & Metaphases & Anaphases & Total cells \\
\hline Paternal sibship with PCD Mean* $(S D)^{* *}$ & $29.49(6.54)$ & $29.81(3.01)$ & $21.79(0.4 \mathrm{I})$ & $27.03(3.05)$ \\
\hline Maternal sibship without PCD Mean* (SD)** & $24.39(3.17)$ & $27.97(1.18)$ & $31.83(3.95)$ & $27.62(1.63)$ \\
\hline Comparison between groups $t$ value & 3.17 & 1.18 & 3.95 & 1.63 \\
\hline Significance & N.S. & N.S. & $P<0.005$ & N.S. \\
\hline
\end{tabular}

$*=$ hours, $* *=$ Standard deviation. Statistical test, t-Student for independent samples.

data of families 1, 4 and 5 in Hanks et al. (2004) [22] report showed also PCD, as well as in 6 of those 15 reported cases update [5]. Considering that subjacent genetic cause was demonstrated to MVA, this opens the possibility that BUB1B defects can be involved in PCD origin. Mitotic spindle checkpoint serves as a surveillance mechanism that ensures the faithful transmission of chromosomes from a mother cell to its two daughter cells during mitosis [23], this can be involved also in PCD origin. On the other hand, because at least 6 genes have been involved with such checkpoint [23], the origin of PCD may be heterogeneous and should involve a mechanism that triggers the whole set chromosome segregation at mitotic spindle checkpoint.

Other aspect to be considered in PCD origin is the centromere. A basic defect of centromeric region in PCD was suggested [19]. Two essential DNA sequences of the centromere were evaluated by FISH in this family: alpha satellite and CENPB-Box sequences. Centromere function requires the presence of alpha satellite DNA in all human centromeres [24]. We observed alpha satellite DNA from all centromeres and the centromere of chromosomes 1, $13 / 21,18$, and $\mathrm{X}$, as well as centromeric 17 bp CENPBBox sequences in prophasic, metaphasic and anaphasic cells from the propositus and his parents. CENPB-Box sequence interacts with the kinetochore protein CENP-B required for the pairing of sister chromatids as structural support and in the conformation of primary constriction and kinetochore [25]. Cytological evidence support the presence of functional centromeres in PCD cells, by positive Cd stain in the propositus and his parents and in one previous PCD report [8]. Also, primary constrictions are evident in this and previous PCD reports. It seems that essential centromere integrity is present and remains unclear if whether or not is involved in PCD origin. Other mechanisms related to cell cycle regulation and functional components of the centromeric region such as defective centromeric cohesion [26], or kinetochore defective proteins are probable.
The PCD trait as a sole chromosome abnormality occurs in healthy individuals. Some authors suggest this PCD trait to be harmless $[1,8,18]$. In this report four individuals presented $\mathrm{PCD}$, and three of them were phenotypically normal. Noteworthy, all the 30 PCD individuals from 9 previous families included in Table 3 were also phenotypically normal. Individuals with this category of PCD have no a recognizable clinical pattern [6-10]. In three of such families clinical findings were informed and reported as coincidental $[6,8,10]$. The abnormal phenotype observed in the propositus shows no concordance to previous PCD without MVA cases. PCD trait observed in healthy paternal relatives and all previous cases, represent the common one dose effect of this autosomal dominant trait (OMIM, *176430) [27]. Such mode of inheritance was concordant with this report because male to male transmission was observed. In autosomal dominant PCD and abnormal phenotype associated to MVA, homozygosity was implicated $[28,29]$. This statement was confirmed by Plaja et al. (2001) [3] in three patients compared with 8 previous cases exhibiting microcephaly, CNS anomalies, mental retardation, prenatal and postnatal growth retardation and cancer, proposing that in vivo occurrence of random aneuploidies and chromosome or genome instability disorder explained some of the clinical data. It seems that variegated aneuploidy is associated to an abnormal phenotype. Our propositus showed prenatal and postnatal growth retardation, profound developmental delay, hypoplasia of the brain and clonic seizures, coincident with MVA reports [5], but our case did not show MVA nor apparent cancer risk. Alternatively, considering that the inheritance of MVA is recessive [5], and some heterozygotes show levels of PCD without variegated aneuploidy, this can be compatible with those individuals described in present report or in previous reports regarding apparently harmless PCD. However, the relationship between PCD and MVA is uncertain [5]. Also, we considered the possibility that neurogical affectation in the patient studied by us could be associated with neonatal hypoxia. In these cases, genetic heterogeneity may be involved. 


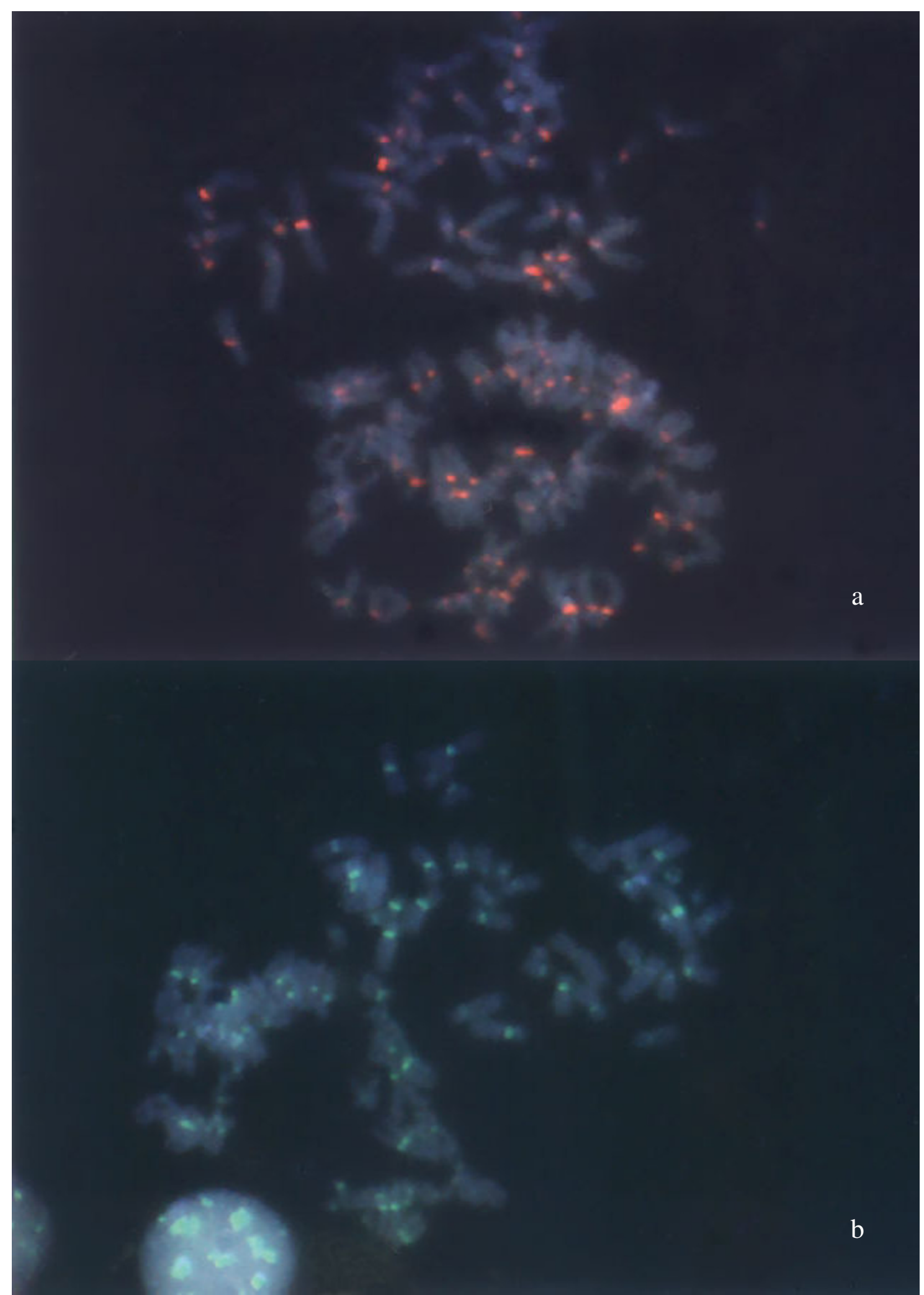

\section{Figure 3}

FISH PCD images. FISH PCD images. All centromeres FISH probe red signals (a), and CENP-B box FISH green signals (b) are shown. 
Table 3: Main features of published families with PCD and present report.

\begin{tabular}{|c|c|c|c|c|c|c|c|c|c|c|}
\hline \multirow[t]{2}{*}{ FEATURES } & \multicolumn{3}{|c|}{ Rudd et al. 1983 [6] } & \multirow{2}{*}{$\begin{array}{l}\text { Gabarrón et } \\
\text { al. } 1986 \text { [7] }\end{array}$} & \multirow{2}{*}{$\begin{array}{l}\text { Madan et } \\
\text { al. } 1987 \text { [8] }\end{array}$} & \multirow{2}{*}{$\begin{array}{l}\text { Bajnoczky and } \\
\text { Gardó } 1993 \text { [9] }\end{array}$} & \multicolumn{3}{|c|}{ Keser et al. 1996 [10] } & \multirow{2}{*}{$\begin{array}{l}\text { Present } \\
\text { report }\end{array}$} \\
\hline & A & B & C & & & & A & B & C & \\
\hline Individuals with PCD & 3 & 4 & 3 & 4 & 4 & 4 & 4 & 3 & I & 4 \\
\hline Individuals with abortion or infertility & $2 / 3 \S \S$ & 0 & $1 / 3 \S$ & $2 / 4 \S$ & 0 & $2 / 4 \S$ & $1 / 4 \S$ & $2 / 4 \S$ & I/I§ & $1 / 4 \S$ \\
\hline PCD in colchicine treated cultures * & $14-15$ & $17-62$ & $10-16$ & $5.2-36$ & $6-12$ & $7-38$ & $6-21$ & $6-28$ & 32 & $5-55$ \\
\hline PCD in untreated cultures * & $7-20$ & $|0-2|$ & $6-6.5$ & $8.5-39$ & $0-3$ & $\mathrm{NI}$ & 17 & 7 & $\mathrm{NI}$ & 5 \\
\hline Controls * & $0-0.5$ & $0-0.5$ & $0-0.5$ & 1 & $0-1$ & $4.1-5.2$ & $0-1$ & 0 & 0 & 0.87 \\
\hline Cd stain & $N I^{* *}$ & $\mathrm{NI}$ & $\mathrm{NI}$ & $\mathrm{NI}$ & + & $\mathrm{NI}$ & $\mathrm{NI}$ & $\mathrm{NI}$ & $\mathrm{NI}$ & + \\
\hline Cell cycle & Short & $\mathrm{NI}$ & $\mathrm{NI}$ & Short & $\mathrm{NI}$ & $\mathrm{NI}$ & $\mathrm{NI}$ & $\mathrm{NI}$ & $\mathrm{NI}$ & Short \\
\hline
\end{tabular}

$*=$ range of percentages. $* *=$ Non investigated. $\S=$ Individuals with abortion. $\S \S=$ Individuals with infertility.

Association of this PCD trait with abortions and infertility has been reported $[6,7,9,10]$. This was observed in 12 of 34 PCD individuals from 8 of 10 previous families including present report (Table 3 ). We observed infertility in two paternal aunts (II-2 and II-3 in fig. 1); cytogenetical analysis was available only in one of them observing PCD. The estimated abortion frequency in descendents of reported PCD individuals was $37 \%$ (22 of 60 ) which is higher than those observed in general population of $15 \%$ [30]. In one report, unexplained recurrent abortion observed in both parents with PCD was considered the consequence of abnormal behavior of the centromeres involving probable homozygous effect [9]. Previous observations are coincidental but remark the occurrence of subfertility in PCD individuals.

\section{Conclusion}

Present report represents a new family with PCD as a sole chromosome abnormality. Cell cycle studies revealed that cell cycle reduction could be considered a distinctive finding in these cases. Based in previous reports and the fact that cells of PCD patients were unresponsive to colchicine is probable that a defective colcemid-induced mitoticspindle checkpoint is involved. Is open the possibility that $B U B 1 B$ defects or other genes involved in such checkpoint may be involved in PCD origin. In this cases considered DNA centromeric sequences were present. It seems that essential centromere integrity is present and remains unclear if whether or not is involved in PCD origin. Other mechanisms related to cell cycle regulation and functional components of the centromeric region may be involved. Interestingly, the PCD trait as a sole chromosome abnormality occurs in healthy individuals and there is not a characteristic associated abnormal phenotype. Only subfertility seems to be a common finding in these families. Those families deserve further investigation in order to understand possible mechanism of this mitotic trait.

\section{Competing interests}

The author(s) declare that they have no competing interests.

\section{Authors' contributions}

AR conceived of the study, and participated in its design and coordination, carried out FISH studies, participated in cytogenetic studies, chromosome analysis, statistical analysis and drafted the manuscript. FS participated in the design and coordination of the study and helped to draft the manuscript. LB participated in the design of the study, helped in clinical activities, helped to draft the manuscript and participated in the statistical analysis. JR participated in clinical activities and drafted the manuscript. CP participated in cytogenetic studies, chromosome analysis and statistical analysis. TG participated in cytogenetic studies, chromosome analysis and statistical analysis. EC participated in the design and coordination of the study, carried out clinical activities and drafted the manuscript. All authors read and approved the final manuscript.

\section{Acknowledgements}

We wish to thank Dr. Lisa G. Shaffer for her valuable comments, and laboratory facilities. We wish to thank to Dr. A. Baldini who kindly provided the CENP-B box biotin labeled probe. We are greatly indebted to Rogelio Troyo Sanromán by his statistical assistance and to Venancio Vazquez by his technical support. This work was supported by CONACYT M-505I and Universidad de Guadalajara funds.

\section{References}

I. Domínguez MG, Rivera H: C-Anaphases: a mitotic variant. Ann Génét 1992, 35: 183-185.

2. Chamla $Y$, Saura R: C-Anaphases and their relationship with mitotic aggregation. Ann Génét 1993, 36:206-210.

3. Plaja A, Vendrell T, Smeets D, Sarret E, Gili T, Català V, Mediano C, Scheres JMJC: Variegated aneuploidy related to premature centromere division (PCD) is expressed in vivo and is a cancer-prone disease. Am J Med Genet 200I, 98:216-223.

4. Kajii T, Ikeuchi T, Yang ZQ, Nakamura Y, Tsuji Y, Yokomori K, Kawamura M, Fukuda S, Horita S, Asamoto A: Cancer-prone syndrome of mosaic variegated aneuploidy and total premature chromatid separation: report of five infants. Am J Med Genet 200I, 104:57-64. 
5. Jacquemont S, Boceno M, Rival JM, Mechinaud F, David A: High risk of malignancy in mosaic variegated aneuploidy syndrome. Am J Med Genet 2002, 109(I): 17-2I.

6. Rudd NL, Teshima HE, Martin RH, Sisken JE, Weksberg R: A dominantly inherited cytogenetic anomaly: a possible cell division mutant. Hum Genet 1983, 65:1 17-121.

7. Gabarrón J, Jiménez A, Glover G: Premature centromere division dominantly inherited in a subfertile family. Cytogenet Cell Genet 1986, 43:69-7I.

8. Madan K, Lindhout D, Palan A: Premature centromere division (PCD): a dominantly inherited cytogenetic anomaly. Hum Genet 1987, 77:193-196.

9. Bajnóczky K, Gardó S: "Premature anaphase" in a couple with recurrent miscarriages. Hum Genet 1993, 92:388-390.

10. Keser I, Lüleci G, Gündüz G: Premature centromere division in three unrelated families. Ann Génét 1996, 39:87-90.

II. Chamla Y: C-Anaphases in lymphocyte cultures versus premature centromere division syndromes. Hum Genet 1988, 78: $111-114$.

12. Denton ET, Brooke WR, Howell MW: A technique for the simultaneous staining of both nucleolar organizer regions and kinetochores of human chromosomes with silver. Stain Technol I977, 52:31।-313.

13. Mitchinson JM: The biology of the Cell Cycle Cambridge, Cambridge University Press; 1971.

14. Ivett JL, Tice RR: Average generation time: a new method of analysis and quantitation of cellular proliferation kinetics [abstract]. Environ Mutagen 1982, 4:358.

15. Palma V, Tudon H, Buentello S, Nava S, Ostrosky P, Salamanca F: Methods for the analysis of cellular kinetics in PHA-stimulated blood lymphocytes using BrdU incorporation. A comparative study. Mutat Res 1993, 286:267-273.

16. Shaffer LG: FISH manual Baylor College of Medicine, Texas Medical Center, Houston Texas; 1996.

17. Matera AG, Ward DC: Oligonucleotide probes for the analysis of specific repetitive DNA sequences by fluorescence in situ hybridization. Hum Mol Genet 1992, I(7):535-539.

18. Ikeuchi T, Yang ZQ, Wakamatsu K, Kajii T: Induction of premature chromatid separation (PCS) in individuals with PCS trait and in normal controls. Am 」 Med Genet A 2004, 127:128-132.

19. Sullivan KF, Glass ChA: CENP-B is a highly conserved mammalian centromere protein with homology to the helix-loophelix family of proteins. Chromosoma 1991, 100:360-370.

20. Matsuura S, Ito E, Tauchi H, Komatsu K, Ikeuchi T, Kajii T: Chromosomal instability syndrome with total premature chromatid separation with mosaic variegated aneuploidy is defective in mitotic-spindle checkpoint. Am J Hum Genet 2000, 67:483-486.

21. Mitchel LS, Liberal V, Chatterjee A, Kirchwegger R, Pasche B, Gerald W, Dobles M, Sorger P, Murty VVVS, Benzra R: MAD2 haplo-insufficiency causes premature anaphase and chromosome instability in mammalian cells. Nature 2001, 409:355-359.

22. Hanks S, Coleman K, Reid S, Plaja A, Firth H, FitzPatrick D, Kidd A, Méhes K, Nash R, Robin N, Shannon N, Tolmie J, Swansbury J, Irrthum A, Douglas J, Rahman N: Constitutional aneuploidy and cancer predisposition caused by biallelic mutations in BUB I B. Nat Genet 2004, 36(I I): I I59-I I6I.

23. Lengauer $C$, Wang Z: From spindle checkpoint to cancer. Nat Genet 2004, 36(I I): I |44- I I45.

24. Voullaire LE, Slater HR, Petrovic V, Choo KHA: A functional marker centromere with no detectable alpha-satellite, satellite III, or CENP-B protein: activation of a latent centromere? Am J Hum Genet 1993, 52:1 I53-II63.

25. Yoda K, Ando S, Okuda A, Kikuchi A, Okazaki T: In vitro assembly of the CENP-B/alpha-satellite DNA/core histone complex: CENP-B causes nucleosome positioning. Genes to Cells 1998, 3:533-548.

26. Nasmyth K, Peters JM, Uhlmann F: Splitting the chromosome: cutting the ties that bind sister chromatids. Science 2000 , 288: I379- I 384 .

27. On Line Mendelian Inheritance in Man. Premature Centromere Division; PCD*I76430 [http://www.ncbi.nlm.nih.gov/ent $\mathrm{rez} /$ dispomim.cgi? id $=176430]$

28. Scheres JMJC, Hustinx TWJ, Madan K, Beltman JD, Lindhout D: A mitotic mutant causing non disjunction in man. Abstracts of the 7th International Congress of Human Genetics. Berlín 1986:163.
29. Kajii T, Kawai T, Takumi T, Misu H, Mabuchi O, Takahashi Y, Tachino M, Nihei F, Ikeuchi T: Mosaic variegated aneuploidy with multiple congenital abnormalities: homozygosity for total premature chromatid separation trait. Am J Med Genet 1998, 78:245-249.

30. Warburton D, Kline J, Stein Z, Hutzler M, Chin A, Hassold T: Does the karyotype of a spontaneous abortion predict the karyotype of a subsequent abortion?-Evidence from 273 women with two karyotyped spontaneous abortion. Am J Hum Genet 1987, 41:465-483.

\section{Pre-publication history}

The pre-publication history for this paper can be accessed here:

http://www.biomedcentral.com/1471-2350/6/33/prepub

Publish with BioMed Central and every scientist can read your work free of charge

"BioMed Central will be the most significant development for disseminating the results of biomedical research in our lifetime. "

Sir Paul Nurse, Cancer Research UK

Your research papers will be:

- available free of charge to the entire biomedical community

- peer reviewed and published immediately upon acceptance

- cited in PubMed and archived on PubMed Central

- yours - you keep the copyright

Submit your manuscript here:

http://www.biomedcentral.com/info/publishing_adv.asp
BioMedcentral 